\title{
The Healthcare System in Spain: From Decentralization to Economic Current Crisis
}

\author{
Marta Aguilar Gil ${ }^{1, *}$, José María Bleda García ${ }^{2}$ \\ ${ }^{1}$ Department of Sociology, University of Seville, Spain \\ ${ }^{2}$ Faculty of Law and Social Sciences, Universidad de Castilla-La Mancha, Spain
}

Copyright $\bigcirc 2016$ by authors, all rights reserved. Authors agree that this article remains permanently open access under the terms of the Creative Commons Attribution License 4.0 International License

\begin{abstract}
Spain's Transition to Democracy set the stage for the organization of a national healthcare system. The adoption of the Spanish Constitution of 1978 was a political milestone that led to the recognition of every citizen's right to healthcare and the right of autonomy of the various regions that make up the Spanish State. The most distinctive characteristic of the healthcare model set up in those early years of political transition was the decentralization of the healthcare system which transferred political and administrative power on matters of public health to the 17 autonomous communities. It took more than 20 years to complete this decentralization process. This evaluative analysis will examine the pros and cons of decentralization. Due to the economic crisis and the election of a conservative government, the National Healthcare System is being seriously questioned, its very sustainability in doubt as reform measures are being taken that are considered a threat by many institutions and organizations to public welfare.
\end{abstract}

Keywords Healthcare System, Spain's Transition to Democracy, Transfer of Public Health Administration, Decentralization of the Healthcare System, Autonomous Communities of Spain, Sociology

\section{Healthcare Policies in the Face of Globalization}

The acceleration of globalization in the 1990s brought with it deep economic, political and social changes on a global level. Healthcare policies were not immune to these changes, as we began to see arguments for a neoliberal state model in opposition to the welfare state, spurring a debate which continues today.

If we carry out a historical review at the global level of modern healthcare systems, we can see how policy is paramount in their formation. Alcántara (2002:24) points out that 'pressure groups, social movements and political parties have had major influence on the formulation of state healthcare policies'. Healthcare went from being considered a private issue, with each individual responsible for taking care of his or her own needs or depending on charity, to being considered a social right of all citizens, with healthcare resources being distributed fairly. The recognition of these social benefits was the result of a long process of social conflict. In Europe at the end of the 19th century and the beginning of the 20 th, 'the working class and the labour movement played an enormous role in the establishment of the welfare state and national healthcare programmes', as Navarro has indicated (1998:851).

The origin of state interventionism goes back to Germany at the end of the 19th century, when Bismarck saw it necessary to establish compulsory health insurance due to protests and the rise of the organized working class within the Social Democratic Party. After the Second World War this model was implemented in the most developed countries and above all in Europe (Bleda 2000:11), beginning the golden age of the welfare state (1945-1975). In Great Britain, for example, the 1948 Labour Party government established the National Health Service with universal coverage provided through general taxes. The welfare state was consolidated during the 1950s and 1960s; at this stage social policy, as Rodríguez Cabrero Argues (1992), was conceived as an autonomous means for social reform within a framework of regulated capitalism. In the 1970s reformist policies entered into crisis due to the stagnating economy and neo-Marxist and neoliberal theories emerged, as the silver age of the welfare state began (1976-2007) ${ }^{1}$. The 1980 s marked the beginning of the discussion on the crisis in the welfare state and new alternatives for social protection were proposed. Neoliberals argue that the welfare state entered into crisis due to its costs, as it leads to an unproductive public sector and unlimited spending. They believe that the privatization of resources is the solution to maintain and improve the welfare state. For neo-Marxists, in contrast, the crisis is not in the welfare state, but rather its

\footnotetext{
1 The idea of a "golden age" and a "silver age" of the welfare state comes from the work of Luis Moreno in his book, La Europa Asocial (2012).
} 
problems result from the essential nature of capitalism. While some talked about the involvement and institutionalization of a broader range of social agents, others suggested that social protection systems must be developed within a process of sustainable growth, flexibility, decentralization and efficiency suitable to neoliberalism. Against this background, it is useful to analyse how, since the 1990s, the impact of globalization has led to a series of changes in healthcare policies at the global level. One of these changes is the loss of power of the state structures which had been responsible for the healthcare system and the arrival of new actors on the scene. For example, beginning at this time, UN institutions involved in the provision of healthcare, as Buse and Walt argue (2000:183), began to increase their activities related to healthcare policies, as did many private firms. This has resulted in an increase in the influence of both the private sector and the UN in healthcare activities on a global level. It was thought that establishing alliances between the public and private sector would benefit healthcare, and would be 'a means to bring together a set of actors for the common goal of improving the health of populations based on mutually agreed roles and principles' (OMS, 1999; cited in Buse and Walt, 2000:184). But recent experience has shown us that the objectives of corporate globalization, such as the search for efficiency and the increase in productivity, are not compatible with objectives such as human development and the struggle against poverty, two fundamental issues that are generally considered the domain of the states. One example of this is in research being carried out for new medicines, which is more influenced by commercial interests than by interest in public health, indicating that the market may be good at achieving efficiency, but not at creating equality.

\section{Liberalization of the Healthcare System in Opposition to the Welfare State}

As was stated in the previous section, the entrance of the private sector in the healthcare system in Europe, based on the model of the neoliberal state, emerged as a response to the so-called "crisis of the welfare state" beginning in the 1980s.

The welfare state was an attempt to find a socially responsive model. As the principle of equality gained force, which was incompatible with a self-regulated market, it led to the idea that the state bears the burden of eliminating all obstacles preventing the less affluent from enjoying formally recognized political and social rights. For this model to be successful it was necessary for it to generate wealth. In theory, according to Keynes, wealth would emerge through the establishment of a consumer economy, which would generate 'an opulent society with extraordinary productive capacity, which would make it possible for the state to allocate a significant share of national revenue for social ends' (Pellinaci, 1988:112). The fall of the Soviet Union produced significant ideological confusion across the world, leading to the triumph of a neoliberal model of capitalism. The main actors in a neoliberal world are the large multinational corporations that control finances, trade and the global IT industry and which are penetrating the increasingly weak borders of the majority of states. In the area of healthcare and social security specifically, 'free-trade agreements have strengthened two powerful economic actors, the insurance industry and the traditional medical-industrial complex' (Laurell, 2000:74). These economic actors have benefited greatly from the state's weakness in intervening in economic matters, thus allowing them to exercise complete control in this area.

In response to this antagonism between the state as provider and the state as passive observer of the market, acknowledging the supremacy of the economic over the political, it is useful to consider alternatives that are compromises between these two institutions. In this regard, it is interesting to consider the search for a better balance and complementarity, in which an active state regulates and guides the undeniable advantages of the market in the production of individual goods, reduces the instability and uncertainty of financial markets, and guarantees the provision of public or socially required goods, including healthcare, which is a basic and vital necessity. This would be an option based on the provision of necessary social protection under a democratic political regime.

This is a description of the situation found in Spain, although it must be taken into account that it was not until the Spanish transition to democracy that Spain began to enjoy the benefits of a welfare state. Approaching the end of the Franco regime, the Social Security Bases Act (1963) established a Bismarckian type insurance system; subsequently, under Spain's initial democratic governments and above all with its integration in the European Economic Community (1986), social policies were extended to cover the majority of the population as in the Central-European and Scandinavian countries; in Spain, however, there was the added peculiarity that with the transfer of competency for healthcare to the Autonomous Communities, almost all Spanish citizens had greater access to and improved healthcare.

\section{Foundations and Goals}

A national healthcare system is generally considered one of the cornerstones of a country's well-being since a healthy population is an indication of a nation's social progress and economic prosperity. In Spain, the healthcare system - as well as the educational system - has its roots in the sweeping social and economic changes that Spanish society underwent during the last quarter of the $20^{\text {th }}$ century. The two most significant legal advances of that era were the adoption of the Spanish Constitution of 1978 - which guaranteed the right of healthcare protection to all Spaniards - and the General Law on Public Health of 1986 - which organized and restructured 
the National Healthcare System and delegated healthcare policy-making to the Autonomous Communities. These measures were based on a set of core values including solidarity, equality, quality and efficiency and have helped Spaniards enjoy a high standard of public healthcare, as shown in several satisfaction polls and as has been publicly stated by various international organizations. However, it is important to recognize that both of these measures were taken amidst a political climate of change when consensus-building was the order of the day. This spirit of cooperation led to an agreement among political parties, healthcare professionals, citizens and unions to set up the legal framework necessary to provide healthcare to the Spanish citizenry.

\section{Legal Measures}

In 1976, toward the beginning of the Spanish Transition to Democracy, the public healthcare system was in disarray. There were many public assistance networks which were financed in a variety of ways, and actual healthcare was in no way connected to a public healthcare system. The Royal Decree/Law 36/1978 on Institutionalization of Social Security, Healthcare and Employment Security reorganized the entire Social Security System and laid the foundation for healthcare protection under the Social Security system which would be provided through one entity: the National Health Institute (INSALUD). Thereafter, INSALUD took charge of administering healthcare services guaranteed under the Social Security system - which included the majority of the public healthcare services available at that time - and acted in a decentralized fashion delegating authority to territorial divisions (provinces and regions).

However, the most important political event of 1978 was the adoption of the Spanish Constitution which acknowledged healthcare assistance as an essential contributing factor to public well-being. Article 43 of the Constitution establishes the right to healthcare protection. Other Articles of the Constitution touch on healthcare matters such as Article 41 which charges the government with maintaining a public system of social security, Article 149.1.7 which gives the State sole authority over general policy and budgetary matters concerning Social Security, and Article 137 which designates the Autonomous Communities as public entities and territorial divisions with rights to political decentralization and autonomization. This set of laws formed the basis for the "principle of minimum expenditure" and made mandatory the allocation of specific funds. The political framework was then in place to universalize healthcare and the foundation was laid for a politically decentralized healthcare system with mandatory allocation of funds. In addition to the aforementioned Articles of the Spanish Constitution, there are other Articles related to public health: Article 45 (environment), Article 49 (handicapped persons), Article 50 (social services), Article 51 (patient and consumer rights) and Article 148 (sanitation and hygiene).

In those early days of Spain's Transition to Democracy, in an effort to guarantee the rights granted by the Constitution, one of the most important legal measures regarding public health was taken to facilitate the organization and restructuring of healthcare: the General Law on Public Health (14/1986 of 25 April). The purpose of this law is to regulate any and all actions taken to ensure the right to healthcare protection for all Spaniards and foreign citizens who have been granted formal residency in Spain. Among its most important general principles are the importance of the healthcare system's role in promoting healthy lifestyles and disease prevention, the need to overcome regional and social inequalities, and gender equality. This Law includes provisions on the authorities granted to certain governmental services, the structure of the public healthcare system, the private healthcare market, and healthcare education and research.

In the late 1970s, $20 \%$ of Spain's citizens were not eligible for public healthcare benefits. However, the aforementioned Law ensured that healthcare was made available to $99.8 \%$ of the population by the beginning of the $1990 \mathrm{~s}$, thereby achieving universal healthcare financed with public funds. This adjustment required hiring more healthcare professionals and building more hospitals as well as shoring up emergency services - the area that had the most room for improvement.

Years would pass before the second of the primary objectives of the General Law on Public Health - delegation of healthcare administration to Autonomous Communities would be achieved (this began in 1981 as will be discussed further on in this article). This goal was reached in two phases: (1) "historical communities" were brought into compliance first, (2) whereafter the remaining communities were brought into line.

This legal framework for the healthcare system has been fleshed out in recent years due to numerous laws on the subject, particularly the Budgetary Law for Autonomous Communities under Ordinary Tax Regulation 21/2001 of 25 December and the Law on Consistency and Quality of Healthcare in the National Healthcare System 16/2003 of 29 May. The former provided national financial support for healthcare services in Autonomous Communities and the latter provided a legal framework for cooperation among the various Public Health Departments in order to ensure fairness, quality and participation in the National Healthcare System which shall play an active role in reducing inequalities in public healthcare.

The following are the principles behind this Law: a) Providing a high standard of healthcare impartially to all beneficiaries of the National Healthcare System, specifically avoiding favouritism to either sex. b) Universal public healthcare provided by the State. c) Cooperation among the various Public Health Departments in order to reduce inequalities in public health. d) A complete commitment to public health including promoting healthy lifestyles, disease prevention, hospital care and rehabilitation, all at a high 
standard of care. e) Public financing of the National Healthcare System in accordance with the then-current system of Autonomous Community financing. f) Equal opportunities and free movement for healthcare professionals throughout the National Healthcare System's network. g) Cooperation between public and private healthcare providers in their services to beneficiaries of the National Healthcare System. h) Cooperation of pharmacies with the National Healthcare System in providing pharmaceutical services. The following are two other laws meant to unify and shore up the Spanish healthcare model: Law 44/2003 on Certification of Healthcare Professionals and Law 55/2003, Statute on Approved Healthcare Service Personnel.

The Autonomous Communities have also been passing new laws to provide a political framework for public healthcare - primarily by way of their Charters of Autonomy - and to bring order and structure to their regional healthcare networks.

The most novel and most important advent in financing the healthcare system was the move from financial backing based solely on workers' contributions to the new model based on the State budget, i.e. general taxation of all citizens. There was a change from the German model (social security) to the British model (national healthcare system).

\section{The Process of Decentralization}

Founded in the General Law on Public Health of 1986, the National Healthcare System encompasses all health systems and services and, in accordance with the provisions of said Law, includes all health services provided by the State and the Autonomous Communities.

- The following are the primary characteristics of the National Healthcare System:

- Universal healthcare for the entire population.

- An organizational framework capable of giving thorough attention to public health, including promoting healthy lifestyles, disease prevention, medical attention and rehabilitation.

- Smooth coordination or unification of all public healthcare resources under one entity.

- The commitments arising from the aforesaid Law are financed using public funds, contributions and fees for certain services.

- Thorough attention to public health at a high standard of care that is subject to appropriate evaluation and monitoring.

To paraphrase Francisco Sevilla, the Councillor of Labour and Social Issues in France (Sevilla, 2006: 17-18), the mission of the National Healthcare System is to guarantee the right to a healthy life and said mission must therefore entail the following responsibilities: 1) Playing an active role in public policy-making in order to ensure the right to healthcare protection, to improve public health and reduce inequalities in healthcare. 2) Ensuring the same standard of healthcare service to all Spanish citizens regardless of where they may live. 3) Ensuring harmonious and consistent cooperation among the various elements of the healthcare system. 4) Providing an effective system for financing public healthcare with the goal of maintaining and improving social cohesion. 5) Making available any improvements in healthcare service or efficiency to the Autonomous Communities.

The National Healthcare System is decentralized and organized in each of the 17 Autonomous Communities. Healthcare is being provided at two levels: primary care and specialized care. Primary care physicians deal with common ailments whereas specialists work with health problems that are more complex and expensive.

The Autonomous Communities have a great deal of independence in their power to pass laws regarding new services - though always within the framework of National law. These Communities are free to allocate part of the public funds granted by the State to hire private healthcare providers, set up new organizational structures, build new healthcare centres, etc. The communities possess a level of self-government that some investigators (Rico et al., 2007: 4) say is greater than any regional government in the world with the exception of the Canadian provinces - and which in practice is quasi-federal. Their responsibilities are administrative and political. This situation makes each community responsible for the standard of healthcare provided therein. As a result, each Autonomous Community bases its Public Health Services on the basic principles the General Law on Public Health (1986). The Regional Healthcare Service includes all healthcare centres, services and public clinics in a particular community. Regional healthcare is organized based on resource allocation factors in accordance with the healthcare needs of the population of the region in question. These regions have their own administrative and monitoring mechanisms, ensure equal participation among the elements of the process of health promotion and health care, and make a Health Plan available to fulfil all of the regional healthcare requirements.

As previously considered, the Spanish Constitution provided for public health administration to be transferred from the State to the Autonomous Communities. This process began in 1981 and came to its completion in 2002 . Catalonia was the first community to create an independent governmental department entrusted with caring for public health, the Catalonian Institute of Health. This served as a model for transferring healthcare protection and public health services for the other Autonomous Communities mentioned in Article 151 of the Constitution (call "historic nationalities"): Andalusia in 1984, Basque Country and Valencia in 1987, Navarra in 1990 and the Canary Islands in 1994. The first phase of the transfer process took 13 years and another eight years would pass for public health administration to be transferred to the remaining Autonomous Communities. So, the decentralization of the public healthcare system required a total of 21 years to come 
to fruition.

Since the Constitution was approved and the first transfers of administration from the National Institute of Healthcare to the historic communities and from other institutes (AISNA, local clinics, etc.) to all regions, the National Healthcare System has ostensibly improved. The primary care reform was carried out. Healthcare was universalized. New healthcare facilities were built (primary care offices and hospitals). More new diagnostic technologies were acquired and training of healthcare professionals improved. In the beginning, the Autonomous Communities that took on public healthcare administration improved services and increased spending more than the Autonomous Communities that depended on INSALUD. It was thought that the new transferring process, as outlined in the Constitution and the General Law on Public Health, would be compatible with or would even promote - fair distribution of healthcare (Lamata, 2002). The decentralization model was based on the supposition that regional administration would offer intrinsic benefits such as greater awareness of the needs of the citizens in that region, closer and more thorough monitoring, and improved access to health services and healthcare for the citizens in that region (more facilities, more services, closer access, and improved healthcare transport services). However, one of the primary goals of decentralization was to reduce healthcare inequalities in communities that are economically less-developed, more isolated and less populated. Some writers (Rico et al., 2007: 26) believe that this process has been successful and that the National Healthcare System is exemplary on an international level since it "presents low spending levels for a developed country, yet has average or above-average results for public health and citizen satisfaction". These writers feel that this model could be used successfully in developing countries. They base this view primarily on the primary care reform and the decentralization of healthcare administration to a regional level, thereby improving equality and reducing former inequalities.

However, public health administrators were very sceptical of decentralization due to the fact that the latest transferences of administration were quite improvised and unclear in its description of which materials, processes, records and methodologies to transfer. They were not sure what to transfer and how. One of the primary reservations was policies regarding spending and personnel, especially given the inequality among the regions: "the inequalities relative to other regions are going to increase as the communities to which public health administration is transferred are going to receive more money... than the communities still depending on INSALUD. The regions with more money and better healthcare systems will have more economic resources which will therefore create, in the beginning, a more marked difference among Spanish regions" (Bleda, 2002: 65). A study conducted by two Spanish universities (González et al., 2004: 87-88) agreed with this point of view. This study underscored regional differences in healthcare reform and the distribution of health services and pointed out inequalities in regional coverage and availability of certain services and programs. This study placed specific emphasis on the unequal number of beds available (especially for geriatric and psychiatric patients) and uneven distribution of cutting-edge medical technology. Furthermore, this study draws attention to the fact that these inequalities are not only regional, but also affect more vulnerable population segments such as children, women and the elderly.

Javier Rey, in his evaluative analysis of the decentralization process (Rey, 1998: 17), postulated that two factors influenced the new decentralized healthcare model: absence of an adequate base model and the lack of "technostructure". When Spain chose its new healthcare model - as described in the General Law on Public Health other countries' National Healthcare Services were used as models, especially those of the United Kingdom and Sweden. However, at that time, those countries were proposing new organizational frameworks to deal with new problems such as spending efficiency and monitoring and new population dynamics. Furthermore, there was a lack of cooperation among healthcare administrators which manifested itself, according to Rey, as a lack of "technostructure" (administrators cooperating collectively): "The lack absence or weakness - of these groups... has generally been filled... by healthcare personnel which due to their specific training and education lack an overall vision of the healthcare system". This weakness is compounded by the instability of the teams of administrators, as administrators are appointed or removed for political reasons when a new party comes to power.

The healthcare decentralization process, in harmony with the General Law on Public Health, required the creation of a National Healthcare System Interregional Council the primary function of which is to coordinate and reconcile the various regional healthcare systems. Subsequently, Article 71 of the Law on Consistency and Quality of Healthcare required the aforementioned Council to adopt a body of regulations which was approved in 2003. These regulations deal with advisory functions, planning, evaluation and coordination within the System. The Interregional Council was created in 1987 was made up of representatives of the National Administration and the Autonomous Communities. After the publication of the Law on Consistency and Quality of Healthcare, the Council was composed of the Minister of Public Health and Consumer Services and qualified healthcare Councillors from the Autonomous Communities and Cities with Autonomous Charters. Furthermore, Article 76 of said Law provided that the State would exercise the faculty of Higher Inspection ("Alta Inspección") as a means of guaranteeing and verifying compliance with national standards and autonomous community standards on public health and healthcare for the National Healthcare System.

This coordinating role has been questioned by some writers (Rey, 1998; Sevilla, 2006), firstly, because coordination has not been fully achieved and, secondly, as public health administration has been transferred, these coordinating services do not have the executive authority 
necessary to do anything other than make recommendations. These services cannot adequately monitor healthcare spending (which the State finances and the Autonomous Communities manage). Their information systems and planning indicators are inadequate and the National Healthcare System is not a force for solidarity and social cohesion.

\section{New Times, Old Debates (2008-2013)}

Twenty years after the implementation of the General Law on Public Health in 1986, a debate was initiated in Spain regarding the success of this legislation and raising the need to revise regulations, correct problems in their application and adapt them to the current times. As a result of this debate, a Health Pact emerged under the progressive government of Rodríguez Zapatero, the aim of which was to agree on common proposals for the reform of the National Healthcare System. The structure of the pact was presented in September 2008 by then Minister of Health, Bernat Soria; whose goal was to uphold the role of the National Healthcare System as a central pillar of the welfare state and as part of the common heritage of the country, which should not only guarantee quality healthcare, but should also be a factor in generating wealth and innovation in the Spanish economy.

From that time until 2011, the Health Pact went through various versions, passed through several commissions within the Congress and the Senate, and was debated in the Interregional Council with numerous professional organizations participating in the discussions regarding its development. Every time there is a change in the government or Ministry of Health (whether progressive or conservative), one of the first things said is how important the Health Pact is and that it is time to get to work, but even now, a number of years after its passage, the debate continues over what to do. Where there is agreement is that the healthcare system is fragile and that all stakeholders in the system must be involved to achieve a consensus on healthcare.

In addition, the need for a new healthcare law is being raised. From a progressive position (see Rey del Castillo) ${ }^{2}$ the desired reform has focused on the following issues: the conditions for healthcare coverage, regional organization, financing, the personnel system, the relationship with the providers of healthcare technology and medication; the aim is to guarantee that the National Healthcare System will be an instrument for social cohesion and will provide universal and equal healthcare to all Spaniards.

However, since the election of the conservative Partido Popular at the end of 2011, the discussion and the actions being taken are posing a challenge to the healthcare system. Since their election, citing the economic crisis, the

\footnotetext{
${ }^{2}$ Rey del Castillo, J. (2006), La universalización de la atención sanitaria. Sistema Nacional de Salud y Seguridad Social, Report No. 86/2006 of the Laboratorio Alternativas, Madrid.
}

conservatives have taken action to reform the General Law on Public Health, the decentralization of healthcare in the Autonomous Communities and the sustainability of the system; in short, they are attempting to modify the healthcare model developed up to this point in time, bringing to the table the old debate between the public and the private. Their most significant action to date was in April 2012, when the government approved a Royal Decree ${ }^{3}$ (in other words, without discussion in the Spanish parliament), Law 16/2012, which, among other things, considered it necessary to carry out an urgent intervention due to: The absence of common rules regarding coverage among all the regions, the uneven growth in the basic portfolio of services, the failure to adapt services to the current socio-economic reality and the lack of rigor and emphasis on the efficiency of the system has led the National Healthcare System into a situation of serious economic difficulty without precedent since its establishment. It is inefficient in the management of available resources, resulting in arrears in payments and an unsustainable deficit in public health accounts. It is therefore essential to adopt urgent measures that guarantee its future and will contribute to preventing the persistence of these problems ${ }^{4}$. The law specifically addresses eligibility, the portfolio of services, pharmaceutical benefits, the financing of the healthcare system, human resources and public health. It is fair to say that this is a "new healthcare law", as it affects nearly all the fundamental aspects of the National Healthcare System.

The new law essentially establishes a new model of healthcare service, which in the opinion of many organizations (professional, civic, trade unions, political) represents an attempt to privatize the healthcare system. In fact, the autonomous communities governed by the Partido Popular had already launched this new model; for example, the Valencian Community, in August 2012, initiated a process to award non-healthcare related logistical management of the Health Department to private firms, with the aim of strengthening a system of public-private collaboration, which, according to the healthcare councillor of this community, will not affect the provision of healthcare, or labour relations for healthcare professionals. However, the autonomous communities governed by the socialists (the Basque Country and Andalusia) are taking steps, either to denounce actions that are weakening the healthcare system, or to protect regional healthcare systems, even challenging the constitutionality of some of these measures, as they modify regulations, rights and competencies.

Since the approval of this law there have been many demonstrations against it, as many fear the dismantling of the public healthcare system, until now based on universality, equality and quality of care and free for users. Many

\footnotetext{
3 Royal Decree-Law 16/2012, de medidas urgentes para garantizar la sostenibilidad del Sistema Nacional de Salud y mejorar la calidad y la seguridad de sus prestaciones [on urgent measures to guarantee the sustainability of the National Healthcare System and improve the quality and security of its services].

${ }^{4}$ Royal Decree-Law 16/2012, BOE [Official State Bulletin] no.98, 24 April 2012, page 31278 .
} 
healthcare organizations (Organización Médica Colegial, la Sociedad Española de Atención Primaria y Comunitaria, Sociedad Española de Medicina Familiar y Comunitaria), trade unions and professional, citizen and consumer organizations have taken actions against the dismantling of the system. They believe that the measures contemplated in the Royal Decree will reverse the advances achieved in the past three decades, setting the country's healthcare system back fifty years, and that these measures will not resolve the problems the system has, but rather will increase costs and lead to greater social inequality. In short, there will be a reverse of and loss of citizens' rights as a neoliberal ideological model places economics before health ${ }^{5}$. Before the crisis of the welfare state in 2007, Spain's public healthcare system provided virtually universal coverage, although the extension of the private management of select healthcare services had begun some time before. The most significant case was the privatization of the management of public healthcare services in the municipality of Alzira in the Valencian Community in 1999. This experience was recently copied by the Community of Madrid in 2012 with the privatization of the management of seven public hospitals, leading to widespread protests by healthcare professions and the public (the so-called "white tide" - because of the white coats healthcare professions often wear). The concerns were that it would worsen healthcare services and increase social inequalities as privatization would not guarantee the sustainability of the system, would reduce its performance and would not provide significant savings. The movement contended that it was not merely the healthcare system that was in danger, but the welfare state itself.

In 2013, healthcare budgets in the Autonomous Communities have been reduced for the third year in a row, leading to considerable social unrest. This is reflected in several studies and reports. A study by the firm, Metroscopia, carried out in January 2013, shows that 73 percent of the Spanish population is on the brink of a social uprising because of the current level of unemployment and poverty. A survey carried out by the Sociedad Española de Medicina Familiar y Comunitaria (SEMFYC) [Spanish Society for Family and Community Medicine] shows that healthcare professionals overwhelmingly reject the privatizing reforms; 96.7 percent prefer solutions that avoid the privatization of healthcare services. In a Social Barometer carried out by the Centre for Sociological Research (CIS) ${ }^{6}$ in 2012, healthcare had risen from being considered the country's twelfth most serious problem in 2011 to its third. Finally, another indicator of the deep discontent felt by the public is the increase in complaints made to Spain's Ombudsman regarding the decline in healthcare services, exclusion from

\footnotetext{
5 The president of the World Trade Organization has proposed the creation of a common organization of medical care in Europe to stop the commercialization of medical practices and the excessive medicalization of society.

The CIS is a public research centre dependent on the Spanish Government. This Barometer, Study no. 2951, measures the public perception of the main problems in Spain and was carried out in June 2012.
}

healthcare protections, payments for medicines, the closing of primary care centres and the lack of sufficient healthcare personnel. In addition to the discontent over these issues, the regulations being established by the current conservative government are also being challenged: all of the Autonomous Communities without conservative led governments are challenging the current reform in Spain's Constitutional Court.

However, this social, professional and political opposition has had no effect on the actions of the central government and conservative regional governments, so the process of healthcare cuts continues and is extending to other communities, such as Catalonia, Castilla-La Mancha, Galicia and Valencia. The unrest felt in Spanish society, which has quickly gone from a so-called golden age of the welfare state to a bronze age, or, in other words, from a period of security to one of uncertainty, is one more example of the Beckian risk society and global insecurity.

\section{Conclusions}

The primary conclusion of this analysis is that Spain enjoys a National Healthcare System that is exemplary and is recognized as such by its citizenry and by international organizations. The System provides universal coverage with the financial backing of the State's general budget that is administered in a decentralized fashion, which should ensure closer, more unified and better informed administration and improved access to health services and healthcare for the citizens of each region. However, clarification is warranted on a few points:

- Healthcare services are in an ever more precarious situation, as in recent years the population has grown $10 \%$ while healthcare resources have not grown at a similar pace.

- Regional differences are being seen in healthcare services in primary health care, specialized care, and in the availability of certain diagnostic technologies and treatment options. This has caused certain social groups to seek these services from private clinics. This could lead to greater inequality and - even more serious - regional differences in service offerings. This would in no way contributed to fairly distributed healthcare throughout the entire State for all its citizens.

- The "technostructure" must be made up of professionals of the highest calibre possible and should not be chosen based on political considerations. Changes must be made in the economic administration of healthcare centres and services.

- The Ministry of Public Health and Consumer Services, the National Healthcare System Interregional Council, and the Higher Inspection do not adequately perform their functions as coordinating and regulating bodies for the new 
managing methodologies adopted by the Autonomous Communities. These governmental bodies must exercise greater control over healthcare spending in order to successfully ensure greater effectiveness, efficiency and fairness, thus contributing to a higher level of democracy and greater sustainability for the System as a whole.

Finally, as indicated by certain sociologists (Bleda, 2008: 45; Irigoyen, 2007: 20-25), we maintain that due to social and cultural changes in modern society as well as changes in government, healthcare policies, and among healthcare professionals, we must take into account the limitations of our resources in order to generate sustainable growth, and we must put more emphasis on promoting healthy lifestyles as opposed to focusing on healthcare alone. This will require a greater participation in the decision-making process on the part of citizens and healthcare professionals and will require a new, more deliberative and participatory model, flexible enough to adjust to a dynamically changing world. With the changing times in Spain, primarily brought on by the current economic and social crisis and the election of the conservative Partido Popular, a new scenario is developing in which old debates over the role of the public and the private sectors are reappearing. All the institutions and organizations involved in healthcare agree that change in the National Healthcare System is necessary, but these changes must be carried out in a manner agreed upon by all stakeholders in the healthcare system and not simply based on the ideology of the governing party.

\section{REFERENCES}

[1] Alcántara, G. (2002) Democracia cosmopolita, Estado moderno y nación. Monografía, Maestría en Ciencias Políticas, CEPSAL, ULA. Mérida, Venezuela. Mimeo.

[2] Appleby, J. and Harrison, A. (2005) Spending on health care. How much is enough? King's Fund. 2005.

[3] Auerbach, L., Donner, A., Peters, D., Townson, H. and Yalnizyan, A.(2003) Funding Hospital Infraestructure: Why P3s don't work, and what will. Canadian Centre for Policy Alternatives. Otawa.

[4] Bauman, Z. (2003) La globalización: consecuencias humanas. Fondo de Cultura Económica, primera reimpresión, Ciudad de México.

[5] Beck, U. (1999) La invención de lo político. Fondo de Cultura Económica. Ciudad de México.

[6] Beck, U. (1998) ¿Qué es la globalización? Falacias del globalismo, respuestas a la globalización. Paidos. Barcelona, España.

[7] Bleda, J.M. (2002) El Estado del Bienestar en la Comunidad de Castilla-La Mancha, Toledo, Ediciones Parlamentarias de Castilla-La Mancha.
[8] Bleda, J.M. (2008) "Salud y sanidad en Castilla-La Mancha (1982-2007)". Felipe Centelles (coord.), Castilla-La Mancha: la consolidación de un proyecto social. Veinticinco años de autonomía, Cuenca, Servicio de Publicaciones de la Universidad de Castilla-La Mancha, 131-145.

[9] Bobbio, N. (1999) Liberalismo y democracia. Fondo de Cultura Económica, quinta reimpresión. Santafé de Bogotá.

[10] Buse, K. y Walt, G. (2000) Global public-private partnerships for health: part I. A new development in health. En: Bulletin of the World Health Organization, No. 78, pp. 49-561.

[11] Campos, P.; Sáez, J. M.; Sánchez, A. (1998) Análisis comparados de sistemas sanitarios. En: Martínez, F.; Castellanos, P. L.; Navarro, V., Salud Pública. McGraw-Hill, Ciudad de México.

[12] Colombo, F. and Tapay, N. (2004) Private Health Insurance in OECD Countries: The benefits and costs for individuals and Health Systems. OECD Health Working Papers.

[13] Cordine, J., Pellathy, T. and Shingal, S. (2009) The role of emotions in buying health insurance. Health Care payers and providers practice. The Mckinsey Quarterly.

[14] Cornejo, E. (2005) Hacia una transformación del Estado en América Latina. En: Nueva Sociedad, No. 199, pp. 104-119.

[15] Cotarelo, R. (1999) Teoría del Estado. En: Díaz, E. y Ruiz, A., Filosofia política II, teoría del Estado. Editorial Trotta, Madrid.

[16] Cremer, H. and Pestieau, P. (2003) "Social Insurance Competition between Bismarck and Beveridge". Journal of Urban Economics, 54, 181-96.

[17] Eriksson, D. and Björnberg, A. (2009) "Euro-Canada Health Consumer INDEX 2009”. FCPP Policy Series, n. ${ }^{\circ} 61$.

[18] Farell, D., Henke, P. and Mango, P. (2007) "Universal principles for health care reform". The Mckinsey Quarterly n. ${ }^{\circ} 1$.

[19] Flores, V. y Mariña, A. (1999). Crítica de la globalidad. Dominación y liberación en nuestro tiempo. Fondo de Cultura Económica, Ciudad de México.

[20] Freire, J.M. (2004) "La atención primaria de la salud y los hospitales en el Sistema Nacional de Salud". En: Navarro, V. Estado de bienestar en España. Barcelona: Tecnos UPF, págs. 239-90.

[21] Gérvas, J., Pérez-Fernández, M., Palomo-Cobos, L. Y Pastor-Sánchez, R. (2005) Veinte años de reforma de la Atención Primaria en España. Valoración para un aprendizaje por acierto/error. Madrid: Ministerio de Sanidad y Consumo.

[22] Giddens, A. (2000) Un mundo desbocado: los efectos de la globalización en nuestras vidas. Taurus, Madrid.

[23] Giddens, A. (1999).La tercera vía. La renovación de la socialdemocracia. Taurus, Madrid.

[24] González, B. et al. (2004) "Oferta pública y privada de servicios sanitarios por comunidades autónomas", Barcelona, Revista Gaceta Sanitaria, v.18 supl.1: 82-89.

[25] Grosse-Tebbe, S. and Figueras, J. (2005) Snapshots of health systems. European Observatory on Health Systems and Policies. 
[26] Health Systems in Transition. (2006) HiT Summary. European Observatory on Health Systems and Plicies.

[27] Healthcast 2020. (2009)Creating a sustainable future. PricewaterhouseCoopers. Health Research Institute.

[28] Irigoyen, J. (2007) "La reinvención de los pacientes ("el cliente siempre tiene razón")", Salud 2000, Revista de la Federación de Asociaciones para la Defensa de la Salud Pública, 113: 20-25.

[29] Kirby, R. (1999) El papel de los medios de comunicación en el proceso de globalización entrando al siglo XXI. Trabajo de Ascenso, Universidad de los Andes, Mérida, Venezuela. Mimeo.

[30] Kolmar, M. (2007) "Beveridge versus Bismarck public-pension system in integrated markets". Regional Science and urban economics, 37: 2007. 649-69.

[31] Lamata, F. (2002) "La equidad en el Sistema Nacional de Salud después de las transferencias", Rev. El Médico, Editorial, 12 January.

[32] Laurell, A. C. (2000) Globalización, políticas neoliberales y salud. En: Briceño-León, R.; De Souza, M. y Coimbra, C. (Coords.), Salud y equidad: una mirada desde las Ciencias Sociales. Editora Fiocruz, Río de Janeiro, pp. 73- 84.

[33] Law 14/1986, 25 April, General Law on Public Health. BOE 102/1986, 29 April 1986. Spain.

[34] Law 16/2003, 28 May, on Consistency and Quality of Healthcare. BOE 128/2003, 29 May 2003. Spain.

[35] Law 21/2001, 27 December, on regulation of taxation and administration in the new financing system for Autonomous Communities under the standard tax regime and Cities with Autonomous Charters. BOE 157/2001, 2 July 2001. Spain.

[36] Mcdaid, D., Merkur, S. and Mladovsky, P. (2008) Health system snapshots: perspectives from six countries. Eurohealth.

[37] Messner, D. (2001) Globalización y gobernabilidad global. En: Nueva Sociedad, No.176, pp. 48-66.

[38] Moracho, O. (2008) Modelos de desarrollo de centros hospitalarios: tendencias y propuestas. Fundacion Alternativas.

[39] Navarro, V. (1998). Sistemas de salud en los países desarrollados. En: Martínez, F.; Castellanos, P. L.; Navarro, V., Salud Pública. McGraw-Hill, Ciudad de México.

[40] OECD Health Data (2008) Statistics and indicators for 30 countries. OECD. IRDES. 2008.
[41] Ornelas, R. (2002) Para una crítica de la globalización. En: Politica y Cultura, No. 17, México, pp. 45-68. Disponible en: www.xoc.uam.mx/ polcul/pyc17/02-orne.pdf (Consulta: noviembre 5 de 2004).

[42] Pellinaci, L. (1988). Estado de bienestar. En: Bobbio, N. y Matteuci, N., Diccionario de Ciencia Política. Siglo XXI, sexta edición, Ciudad de México.

[43] Pestieau, P. (2006) The Welfare State in the European Union, economic and social perspectives. Oxford University Press. Oxford.

[44] Programa de las Naciones Unidas para el Desarrollo, PNUD (2003). Informe sobre el desarrollo humano 2003: los objetivos del milenio, un pacto entre las naciones para eliminar la pobreza. Ediciones Mundi Prensa, Madrid.

[45] Purton, H. (1996) "European Welfare States in the 1990's: An economic analysis of the challenges and efforts at reform". CEPS Research report, 19.

[46] Rechel, B., Wright, S., Edwards, N., Dowdeswell, B. and Mckee, M. (2009) Investing in hospitals of the future. World Health Organization.

[47] Rey, J. (1998) “Análisis del origen, situación y perspectivas de futuro del proceso de descentralización sanitario español”, Revista Española de Salud Pública, Madrid, vol 72, 1: 13-24.

[48] Rico, A., Freire, J. M. and Gérvas, J. (2007) "El sistema sanitario español (1976-2006): Factores de éxito en perspectiva internacional comparada". En Álvaro Espina (coord.), Estado de bienestar y competitividad: la experiencia europea,Madrid, Fundación Carolina, Siglo XXI, 401-444.

[49] Riutort, B. (2001) Derechos y capitalismo global. En: Leviatán: revista de hechos e ideas, No. 83, pp. 69-93.

[50] Royal Decree-Law 36/1978, 16 November, on Institutionalization of Social Security, Healthcare and Employment Security. BOE 276/1978, 18 November 1978. Spain.

[51] Saltman, R., Bankauskait, V. and Vrangback, K. (2007) Decentralization in health care. Strategies and outcomes. McGraw-Hill. Open Press University.

[52] Sevilla, F. (2006) La universalización de la atención sanitaria. Sistema Nacional de la Salud y Seguridad Social, Fundación Alternativas, Documento de trabajo 86/2006.

[53] Spanish Constitution of 27 December. BOE 311/1978, 29 December 1978. 